\title{
Socio-Economic Barriers against Women Equal Right in the Society (a Case of Bangladesh)
}

\author{
Masuma Akter \\ Fareast International University, Dhaka, Bangladesh \\ Email: soniabd1@hotmail.com
}

How to cite this paper: Akter, M. (2018) Socio-Economic Barriers against Women Equal Right in the Society (a Case of Bangladesh). Open Journal of Social Sciences, 6, 156-166. https://doi.org/10.4236/jss.2018.67012

Received: June 6, 2018

Accepted: July 27, 2018

Published: July 30, 2018

Copyright (C) 2018 by author and Scientific Research Publishing Inc. This work is licensed under the Creative Commons Attribution International License (CC BY 4.0).

http://creativecommons.org/licenses/by/4.0/

\section{cc) (i) Open Access}

\begin{abstract}
This study attempts to focus on the socio-economic barriers which play a significant role against establishing women's equal right in the society. The overall social and economic development of a country depends on the equal right for both men and women. However the social and economic condition of women in the third world countries is getting worse day by day. Moreover they are being deprived and neglected in every sphere of life. Their unequal position of right in the society simply means that they have less power, property, status, privilege than that of man. Like other third world countries the overall position of women in Bangladesh is not good at all. This paper's aim is to find out and discuss the major social as well as economic barriers which play a prominent role against women's equal right in Bangladesh.
\end{abstract}

\section{Keywords}

Equal Right, Social Barriers, Economic Barriers

\section{Introduction}

In Bangladesh inequality between men and women persists from the very beginning of the society and the inequality is found in every sector of life. Most of the people believe that women do not deserve equal treatment than that of men do. From the early childhood girls are neglected in the society. Moreover the birth of male child is welcome on the other hand that of female child is considered as a curse. Girls are considered as the burden of the society due to superstition, religious sentiment, social customs etc. Furthermore they are considered as the reproductive tool of the society and encouraged to keep themselves busy with household activities. They are being dominated by a patriarchal kinship system which mainly reflects their subordination and unequal status in the society. Most of the time women need to rely upon men throughout their whole lives. Conse- 
quently, women are not getting fair access to education, health, employment, property and influence. The scenario is getting worse day by day. Poor education system as well as drop out from the school has become another common problem which has been shown in Table 1 . The literacy rate for female and male was $69.90 \%$ and $75.62 \%$ respectively in 2016 . The rate of women violence including domestic violence as well as physical and mental harassment outside the home has been increased. The number of domestic violence and dowry related violence was 397 and 395 respectively in 2010 which we can see from Table 5. Most of the women are living in below poverty line. The poverty rate among the women is getting high due to unfavorable working place, lack of family support, wage discrimination; poor security system and so on. Sometime they are pushed to migrate other places due to economic hardship. The rate of women participation in politics is very low. The number of female parliament member was 4.8 (out of 315) in 1973 and 13.03 (out of 330) in 1996 respectively which is shown in Table 2. A study conducted by Action Aid titled "The cost of inequality in women's work" found that the average earnings of women in Bangladesh are $60 \%$ of those of men for the same amount of work. "The participation of women in the economy may have increased, but they are mostly in low-paid and low-skilled jobs", said Centre for Policy Dialogue Distinguished Fellow, Professor Rounaq Jahan [1]. According to BBS estimates, 33.5\% of the labor force in Bangladesh is female. According to the estimation of 2016, the number of female

Table 1. Bangladesh-literacy rate.

\begin{tabular}{ccc}
\hline DATE & Adult literacy rate female & Adult literacy rate male \\
\hline 2016 & $69.90 \%$ & $75.62 \%$ \\
2011 & $46.74 \%$ & $47.45 \%$ \\
2007 & $43.74 \%$ & $49.83 \%$ \\
2001 & $40.82 \%$ & $53.90 \%$ \\
1991 & $25.84 \%$ & $44.31 \%$ \\
1981 & $17.97 \%$ & $39.73 \%$ \\
\hline
\end{tabular}

UNESCO Institute for Statistics (UIS) 2016.

Table 2. Elected women's members to the Bangladesh parliament (1973-2001).

\begin{tabular}{lccccc}
\hline Year & \% of female candidates & Won & Total elected & Reserved Seats & In parliament (\%) \\
\hline 1973 & 0.3 & 0 & 0 & 15 & 4.8 (out of 315) \\
1979 & 0.9 & 2 & 2 & 30 & 9.69 (out of 330) \\
1986 & 1.3 & $5+2$ & 7 & 30 & 11.21 (out of 330) \\
1988 & 0.7 & 4 & 4 & 0 & 1.33 (out of 300) \\
1991 & 1.5 & $8+1$ & 9 & 30 & 11.81 (out of 330) \\
1996 & 1.36 & $13+2$ & 15 & 30 & 13.03 (out of 330) \\
2001 & 1.79 & 6 & 6 & 0 & 2.00 \\
\hline
\end{tabular}

Source: Election Commission of Bangladesh (2001). 
employees was 16.1 in industrial sector and 20.8 in service sector respectively. The details about female employee have been added in Table 3. Generally, women are not present in top tier jobs because there is no supply or they are overlooked in favor of men. The gender gap indicators are being skewed by the high proportion of women working in the ready-made garments (RMG) sector [2].

\section{Socio-Economic Barriers Associated with Women Equal Right}

Not a single factor is responsible for the prevailing condition of women in the society. There are some significant factors or barriers which play prominent role against establishing women's' equal right in the society such as illiteracy, lack of social awareness, unfavorable social norms \& values, patriarchal social system, poverty, high rate of women unemployment, lack of participation in politics, responsibility towards family members and so on. Some of the barriers are discussed as follows:

\subsection{Role of Poor Education System against Women's Equal Right}

Education plays a vital role in improving our attitude and the way of our thinking. In addition it helps to change our social status and life style. An educated woman can play a significant role in increasing household income, poverty reduction, providing better educational facilities to her children, get better breast feeding, and better hygiene and so on. However the literacy rate of women in Bangladesh is very poor. Women are disadvantaged in the field of education. In order to limit their contact with males, girls are often taken out of school when they reach puberty [3]. Bangladesh Bureau of Statistics presents a report where we can find that the percentage of illiterate women in the country is increasing, as is the gap between literate men and women. BBS's Literacy Assessment Survey (LAS) 2011, released in May 2013, shows that 52.1 per cent of women-past 15 years of age-are illiterate, while 45.4 per cent of men are illiterate. Women in rural areas are 55.5 per cent illiterate while 39.2 women in urban areas are illiterate [4]. According to the Education for All global report 2013-14, launched in June 2014 in Bangladesh, 42 per cent women will remain illiterate, against 35 per cent men, by 2015 . The report said that 47 percent female and 38 percent male

Table 3. Female employees in Bangladesh (in percent of total employee).

\begin{tabular}{ccc}
\hline Sector & Year (2013) & Year (2016) \\
\hline All sectors & 32.8 & 28.5 \\
Industrial & 23.7 & 16.1 \\
Manufacturing & 22.5 & 14.9 \\
Service & 22.8 & 20.8 \\
Agriculture & 53.5 & 63.1 \\
\hline
\end{tabular}

Source: Bangladesh Institute of Development Studies (BIDS). 
were illiterate in 2011. The Bureau of Non-Formal Education estimates that 45 percent female and 37 male are illiterate. The literacy rate of female and male in Bangladesh estimated by UNESCO is given as follows.

From the above data we can see that the literacy rate for female and male was $17.97 \%$ and $39.73 \%$ respectively in 1981 . Over the period, the literacy rate for females has risen from $17.97 \%$ to $69.90 \%$, and for males from $39.73 \%$ to $75.62 \%$. The data estimated by UNESCO mainly indicates that the increasing literacy rate of men is higher than that of women in Bangladesh [5]. The lower increasing literacy rate for women as well as drop out from education can be considered as a prominent barrier against establishing equal right for women in Bangladesh [6]. The government's statistics from BANBEIS show that in 2015, the national dropout rate in the secondary level was $40.29 \%$, out of which $45.92 \%$ were girls and $33.72 \%$ were boys. That number slightly decreased last year with an overall dropout rate at of $38.30 \%$ with $42.19 \%$ being girls and $33.80 \%$ being boys. Most of the female students under class VIII and IX drop out from school because of child marriage, poverty. $29 \%$ of girls get married before age 15 and $65 \%$ before the age of 18 . Government action has had little effect, and has been contradictory: although the government has pledged to end child marriage by 2041 [7].

\subsection{Role of Violence against Women's Equal Right}

Violence against women has become a very common scenario in Bangladesh. The most common acts of violence committed against women includes dowry killings, rape, sexual harassment, stalking, acid attacks, physical and mental abuse and sex trafficking. In 2004, 2981 cases were estimated of dowry related violence; where women were beaten or killed because their parents could not pay the dowry to the girl's in-laws. This number rose to 4563 cases in 2012. A research titled Violence against Women Survey 2011, conducted by the Bangladesh Bureau of Statistics in collaboration with the United Nations Population Fund shows that 77 per cent of respondents admitted that they had been abused. Of these, 50 per cent had sustained serious injuries, but one in three women refused to go to hospital for fear of retaliation by the husband. According to Dhaka (Asia News, March 2, 2014) -About 87 per cent of Bangladeshi married women are abused by their husband, this according to a nation-wide study conducted by the government that involved a sample of 12,600 women [8].

\subsection{Role of Wage Discrimination and Unfavorable Workplace against Women's Equal Right}

Majority of the women work in the low-paid and less skilled jobs, where work hazards are comparatively higher (Paul-Majumder, 2003).The 2007 Bangladesh Occupational Wage Survey reveals very low average hourly wages of 16.8 taka, the equivalent of approximately 25 cents/hour in current 2007 US\$, or about $\$ 1.21$ per hour at purchasing power parity exchange rates. The survey results also highlight the existence of a significant and persistent gap in earnings between 
women and men: on average, men in the surveyed industries earn over 21 per cent more per hour of work than women. Although there are constitutional guarantees of employment equity, in practice women have limited job opportunities [9]. In addition they also suffer from low wages and irregular wage payment. In fact, a large number of female workers received wages below the minimum wage rate fixed by the Government of Bangladesh. Moreover sexual harassment of women has become a very common issue in the workplace of Bangladesh. This sort of harassment creates mental pressure in their mind. Such problem of harassment or physical assault in the work place discourages them to continue their job. They are vulnerable to physical, psychological and sexual abuse in the work place. The condition of garments female workers is more vulnerable. Now a day, more than 4000 garment factories of Bangladesh are being contributed about 76 percent of the country's export earnings [10]. Most of the garments workers are female and they are being exploited as the cheap source of labor. Moreover harassment by male colleagues has become a very common issue which is responsible to decreasing their participation in the workplace. According to World Bank President Jim Yong Kim "Countries such as Bangladesh are encouraging female participation in the workforce. If they [Bangladesh] stay on track, their female workforce will grow from 34 to 82 percent over the next decade, adding 1.8 percentage points to their GDP" [11]. According to Bangladesh Labor Force Survey 2010, labor force participation for women is 36 percent, compared to 82.5 percent for men. Bangladesh's women participation in labor force can highly be influenced by creating favorable access in rural agricultural areas as well as industrial sectors such as garment industries [12].

\subsection{Role of Malnutrition and Poor Health System against Women's Equal Right}

Despite of achieving progress in medical and health sector the condition of female health is still in a vulnerable position. Most of the poor women suffer from poor nutrition, frequent illness and access to health facilities. Sometimes they fail to fulfill their responsibility due to poor health condition and malnutrition. Maternal malnutrition during pregnancy increases the risk of mortality, as well as it affects fetal growth. Female child mortality rate is higher than that of male child. Unnayun Aunnasha reported that the child mortality in case of male was 46.7 per thousand live births in 1993-1994, which has decreased to 16 per thousand live births in 2007 with an annual average decreasing rate of 2.19 per thousand live births. On the other hand, for female, it was 62.3 per thousand live births in 1993-94, which has been decreased to 20 per thousand live births in 2007 with the average decreasing rate of 3.02 per thousand live births per year [13].

\subsection{Role of Poverty against Women's Equal Right}

Poverty denotes as a state or condition whereas a person or community lacks the financial resources and essentials to enjoy a minimum standard of life and 
well-being that's considered acceptable in society. In Bangladesh, women are vulnerable to extreme poverty because they face greater burdens of unpaid work. Moreover have fewer assets and productive resources than men. Most often they are forced to get married at the very early stage without their consent. All these reasons play a vital role against their participation in economic field and make them vulnerable to extreme poverty level. The incidence of poverty, among female headed households has dropped from 29.5 per cent in 2005 to 26.6 per cent in 2010 with an annual rate of 1.97 per cent. Whereas, the incidence of poverty for male headed households has fallen from 40.8 per cent in 2005 to 32.1 per cent in 2010 with an annual rate of 4.26 per cent during the same time. The rate of reduction in the percentage of incidence of poverty was 3.27 per cent and 2.64 per cent per annum respectively for female headed households and male headed households between 1995-'96 and 2010. The incidence of poverty in female headed households has decreased to 26.6 per cent in 2010 at the national level with an annual rate of 1.97 per cent from 2005. If this rate of decrease continues, the incidence of poverty in female headed households might slide down to 25.03 per cent and 20.85 per cent by 2013 and 2021, which is higher by 0.03 per cent and 5.85 per cent respectively than those of the targets of the present government [13].

\subsection{Role of Poor Accessibility in Politics against Women's Equal Right}

In Bangladesh, an unequal power relation is existed in the political field. Most of the time women are being discouraged to participate in the political sector due to social norms and values. Moreover they are also being discouraged by their family members. Though our prime minister and few other political leaders are women but majority of the political figures are male. So the whole political system is being dominated by the male politicians who are unfortunately not willing to promote women leaders in vital political issues. In the 1979 parliamentary elections, for example, only 17 women were among 2125 candidates for 300 seats; none of the women won and only 3 polled over 15 percent of the vote. At the union council level, the 1973 elections returned only one woman chairman, and the 1977 and 1984 elections each returned only four female chairmen. From the 1st parliament to the $8^{\text {th }}$, the number of women elected for general seats were minimal. In order to ensure proper representation of women, the $14^{\text {th }}$ amendment of the Constitution has reserved 45 seats for women in the $9^{\text {th }}$ parliament. In the $10^{\text {th }}$ parliament 5 more seats were added and it reached at 50 . However 50 seats are not enough to represent women in whole political field, where 300 seats are mostly dominated by men [14]. If we deny ensuring the equal right for girls and women, the whole society will be the sufferer. We need to provide the adequate access and opportunity for women in political sector so that they can show their talents as well as eligibility like men. The Bangladesh Election Commission has taken a step towards strengthening women's political participation by imposing a 33 percent reservation for women in all political parties' executive committee positions including the central committee by 2020 [15]. However, progress towards this goal has been very 
slow.

From the above data we can see that the percentage of female candidate of Bangladesh Parliament was 0.3 in 1973 and 1.79 in 2001 respectively. The number of reserved seat for women was 15 in 1973 and 30 in 1996 respectively. The number of female parliament member was 4.8 (out of 315) in 1973 and 13.03 (out of 330) in 1996 respectively. So we can see that the increasing rate of female member in Bangladesh Parliament is very low.

\subsection{Role of Patriarchal Social Structure against Women's Equal Right}

Bangladesh is mainly a patriarchal society. Patriarchy is considered as the prime obstacle to women's advancement and development. In most of the family women do not have the power of decision making. In addition women have to play a prime role in the family such as biological reproducers and nurturers. Moreover women are ought to do all the domestic household chores, child bearing and so on. However they do not have any controlling power within the household because of the patriarchal social structure. All the vital decisions of women's life such as their education, participation in the job market, marriage issue etc. is taken by the male member of the family. Patriarchy mainly ensures women dependence and subordination on men in every sphere of life. Consequently men enjoy all the power and authority within the family and the society. So we can say that, the patriarchal system of Bangladesh plays a vital role against establishing women's equal right in the society.

\subsection{Role of Socio-Cultural Norms and Values against Women's Equal Right}

Women position in the society is highly influenced by the Socio-cultural norms and values. However the socio-cultural norms and values in our society are not at all favorable to establish women equal right in the society. Most of the time early \& forced marriage, drop out from school, early pregnancy, violence against women, lack of decision making power etc are badly influenced by socio-cultural norms and values.

\section{Materials and Methods}

The paper on “socio-economic barriers against women's equal right in the society" has been prepared by taking secondary data from different journals, annual reports, surveys, administrative records of different ministries/division and report from Non Government organizations and so on.

\section{Results and Discussion}

After reviewing all the data and findings it can be said that lack of better educational facilities, domestic violence, harassment in work place, unfavorable social norms and values, poverty, high unemployment rate of women, patriarchal so- 
cial attitudes, child marriage etc work together as the major hindrance of establishing women's equal right in Bangladesh. Women are getting vulnerable due to lack of job opportunities along with economic hardship. At the job market, women do not get the same job opportunities and receive fewer wages for the same work, compared to their male colleagues. The labor force participation rate of the population aged 15 or older at 58.5 Percent, at 81.9 percent male and 35.6 percent for females [16]. Most of the poor women have to work hard with little wages due to the lack of skills, education and absence of adequate social protection. Women's income may impact in reducing their poor condition. Moreover the earnings of women in the households enhance their decision making ability and improve their quality of lives. In urban areas, the number of women earners has increased from 943 thousands in 1995 to 2037 thousands in 2010 with an annual rate of 7.73 percent. Rural poverty among women results from lack of assets, limited economic opportunities and poor education and capabilities as well as disadvantages rooted in the social and political inequalities [17]. Bangladesh women employment rate is lowest than any other South Asian country. Percentage of earners among women household members increased from 12.9 in 2005 to 15.0 in 2010. According to the World Bank data for Bangladesh from 1990 to 2017, the female labor force participation rate in Bangladesh during that period was 27.71 percent with a minimum of 23.11 percent in 1990 and a maximum of 33.04 percent in 2017 [18]. The female Employees in Bangladesh is shown in Table 3.

From the above data estimated by Bangladesh Institute of Development Studies (BIDS) we can see that the number of female employees was 32.8 in 2013 and 28.5 in 2016 respectively for all the sectors. So the rate of female employees for all the sectors has been decreased in 2016. The same scenario is visible in industrial, manufacturing and service sector too.

Most of the women are mainly involved in household activities, poultry rising, cultivation of crops, animal husbandry, gardening and so on. All of these activities are homestead based activities and considered as domestic responsibilities or duties of women. Moreover these shores are also considered as non-productive as well as economically unpaid activities. Whereas men are highly involved in productive or economic activities such as cultivation of land, poultry farming, shop keeping, business, service and so on.

From the above data of Table 4 shows that women participation in agricultural, manufacturing, community, social and personal Service sectors are higher than that of men though they are getting lower wages than that of men. However we can see the less participation of women in the rest of the sectors than that of men [19].

According to human rights organization Bangladesh Mahila Parishad (BMP), 5616 cases of violence against women were recorded in 2012, mostly rapes (904), followed by murders (900), stalking and death as a result of stalking (662); dowry-related murders (558), and suicide (435) [20]. A report against women 
Table 4. Sector based composition of employment by gender (2003).

\begin{tabular}{ccc}
\hline Sector & Men & Women \\
\hline Agriculture/Fisheries & 49.8 & 58.7 \\
Mining & 0.2 & 0.0 \\
Manufacturing & 7.6 & 17.7 \\
Utility & 0.3 & 0.1 \\
Construction & 4.2 & 1.0 \\
Trade, Hotel, \& Restaurant & 18.6 & 2.5 \\
Transport, Storage, \& Communications & 8.7 & 0.3 \\
Finance \& Business & 0.6 & 0.2 \\
Community, Social, \& Personal Services & 9.9 & 20.1 \\
\hline
\end{tabular}

Source: BBS (LFS) for Bangladesh, World Bank, 2004.

Table 5. Violence against women: Types and trends.

\begin{tabular}{ccccccc}
\hline Year & $\begin{array}{c}\text { Domestic } \\
\text { Violence }\end{array}$ & $\begin{array}{c}\text { Dowry Related } \\
\text { Violence }\end{array}$ & Rape & Gang Rape & Acid Attack & $\begin{array}{c}\text { Eve teasing/ } \\
\text { Stalking }\end{array}$ \\
\hline 2004 & 264 & 352 & 618 & 359 & 228 & \\
2005 & 333 & 356 & 585 & 250 & 130 & \\
2006 & 301 & 334 & 515 & 226 & 142 & \\
2007 & 283 & 294 & 436 & 198 & 95 & \\
2008 & 312 & 296 & 486 & 127 & 80 & \\
2009 & 281 & 285 & 446 & 199 & 63 & 216 \\
2010 & 397 & 395 & 626 & 290 & 153 & \\
\hline
\end{tabular}

Source: Redrawn from Ain O Salish Kendra (ASK) Documentation Unit, 2011 and Odhikar, 2011.

violence provided by Ain O Salish Kendra (ASK) published in 2011 is given below in Table 5.

We can see from the above data that the number of domestic violence has been increased from 264 in 2004 to 397 in 2010 respectively. In addition dowry related violence, rape cases have also been increased at an alarming rate [21]. So the abusing rate of women is getting higher day by day. If we deny ensuring the equal right for girls and women, the whole society will be the sufferer. We need to provide the adequate access and opportunity for women in political sector so that they can show their talents as well as eligibility like men. The Bangladesh Election Commission has taken a step towards strengthening women's political participation by imposing a 33 percent reservation for women in all political parties' executive committee positions including the central committee by 2020 . However, progress towards this goal has been very slow.

\section{Conclusions}

From the above discussion it is very obvious that women in Bangladesh face bar- 
riers and disadvantages in nearly every aspect of their lives. They usually have limited access to health services, economic opportunity, political participation, control of finances and so on. Women empowerment can play a significant role to reduce gender discrimination from the society. We can see that women participation in political sector is very low and society does not appreciate their presence in politics at all. Social awareness can play a vital role to change such attitudes towards women. Some effective planning and strategies taken by the government may change women's economic as well as social life. There are some harmful customs like early marriage, dowry system, abandonment by husbands make them more vulnerable. Violence against women is not only seen at home but also at public places even at working places. A national survey carried out by the Bangladesh Bureau of Statistics (BBS) in 2011, shows that as many as $87 \%$ of currently married women reported having experienced both physical and psychological violence.

UNDP focuses on gender equality and women's empowerment not only as human rights, but also because they are a pathway to achieving the Millennium Development Goals and sustainable development.

In order to reduce the obstacles against establishing women's equal right in Bangladesh we can take the following measurements:

1) Educational facilities for all the women must be ensured.

2) Early and forced marriage should be stopped at any cost.

3) Women equal and easy access to political field should be encouraged.

4) Existing laws regarding protection of women's rights should be enforced effectively.

5) Socio-cultural norms, values and attitudes towards women should be changed.

6) Any sort of violence against women should be prevented.

7) Women participation in economic field should be ensured.

8) Awareness of gender equality should be raised in the society.

9) Media \& other non-government organization can help to create awareness among women to establish their right in the society.

10) Opportunities of training for self dependency should be ensured.

\section{References}

[1] Jahan, R. (2017) Women's Participation Increased Mostly Low Paid Low Skilled Jobs. Dhaka Tribune.

[2] (2017) Is Bangladesh Really Closing the Gender Gap? Dhaka Tribune. https://www.dhakatribune.com/bangladesh/2017/11/08/bangladesh-really-closing-g ender-gap

[3] Bhuiyan, R. (1991) Aspects of Violence against Women. Institute of Democratic Rights, Dhaka.

[4] Bangladesh Bureau of Statistics (BBS) (2013) Literacy Assessment Survey 2011. May 2013.

[5] UNESCO Institute for Statistics (UIS) (2016) Results of the 2016 UIS Education 
Survey.

[6] Child Education and Literacy Survey 2002, Compulsory Primary Education Implementation and Monitoring Unit, Ministry of Primary and Mass Education, Government of Bangladesh.

[7] Bangladesh Bureau of Educational Information and Statistics (BANBEIS), 2015.

[8] Asia News. Violence against Women and Girls Program. 2 March 22014.

[9] Begum, Sultana, Ferdousi, Gender Equality and Women's Empowerment: Suggested Strategies for the 7th Five Year Plan, December 2014.

[10] BGMEA Report, 2008. http://www.bgmea.com.bd/home/pages/tradeinformation

[11] Rahman, F. and Byron, K.R. Women Workforce Growing Fast. https://www.thedailystar.net/frontpage/women-workforce-growing-fast-155149

[12] Bangladesh Labor Force Survey 2010. http://www.ilo.org/surveydata/index.php/catalog/1125

[13] Gender Inequality in Bangladesh-Unnayan Onneshan Policy Brief. http://www.unnayan.org/documents/GenderRights/policy_brief_gender_inequality. pdf

[14] Bangladesh Women in Politics. http://countrystudies.us/bangladesh/103.htm

[15] Election Commission of Bangladesh (2001). http://www.ecs.gov.bd/page/election-commission-secretariat?lang=en

[16] Bangladesh Bureau of Statistics (BBS) (2008) Report of the Labor Force Survey, Bangladesh, 2005-2006. Bangladesh Bureau of Statistics, Dhaka.

[17] IFAD's Work and Results in the 2010. https://www.ifad.org/web/knowledge/annual-reports

[18] World Bank Report. https://www.theglobaleconomy.com/Bangladesh/Female_labor_force_participation

[19] BBS (LFS) for Bangladesh. World Bank, 2004. http://siteresources.worldbank.org/SOUTHASIAEXT/Resources/Publications/4488 13-1185396961095/403055

[20] http://www.asianews.it/news-en/In-Bangladesh,-87-per-cent-of-women-victims-ofdomestic-violence

[21] Redrawn from Ain o Salish Kendra (ASK) Documentation Unit, 2011 and Odhikar, 2011 . 